\title{
Comparison of Catastrophizing and Perceived Stress in Three Groups of COVID-19 Patients Recovered
}

\author{
Dr. Peyman Dousti ${ }^{1 *}$, Narges Hosseininia ${ }^{2}$, Pegah Dousti ${ }^{3}$, Shabnam Dousti ${ }^{4}$
}

\section{ABSTRACT}

The aim of this study was to compare catastrophizing and perceived stress in three groups of Covid-19 patients recovered. This was a descriptive study. The statistical population of this study was the visitors of Avaye Dousti Clinic psychometrics system from October to December 2020. From this population, 97 people who met the inclusion criteria was positive, were selected by purposive sampling method. Volunteers were divided into three groups: patients with respiratory symptoms and hospitalized $(n=22)$, patients with respiratory symptoms and non-hospitalized $(n=27)$ and patients without respiratory symptoms and nonhospitalized $(\mathrm{n}=48)$. Measurement tools of this study included Sullivan (2009) catastrophizing Questionnaire and Cohen et al (1983) Perceived Stress Questionnaire. Data were analyzed by analysis of variance using. The results showed that catastrophizing, mental rumination, helplessness and magnification were not significantly different, between the group with respiratory symptoms and hospitalized and the group with respiratory symptoms and non-hospitalized ( $>>0.05$ ), but the same variables in the group without respiratory symptoms and non-hospitalized, Was less than the two groups $(\mathrm{p}<0.05)$. Perceived stress was not significantly different between the three groups $(p>0.05)$. The findings of this study showed that catastrophizing in patients with Covid-19 disease is seen in patients with more severe symptoms for at least a few months after recovery and high perceived stress was observed in all patients without significant differences.

\section{Keywords: COVID-19, Catastrophizing, Perceived stress, Patients with Respiratory Symptoms}

$\mathrm{T}$ he new corona virus started in December 2019 in Wuhan, China, and soon spread to other parts of the world. The virus is not associated with serious illness in some people, but in others it causes respiratory problems and severe symptoms, and in more severe cases, some people need hospital care (Dousti, Hosseininia, Ghodrati \& Ebrahimi, 2020). With the global outbreak of the virus and the shift from epidemic to pandemic, quarantine has taken on a more serious color and odor to prevent further spread of the virus, and findings show that quarantine and the Covid-19 stressors have high negative mental health outcomes. $17.3 \%$ were associated with depression, $20.8 \%$ with anxiety, $7.3 \%$

\footnotetext{
${ }^{1}$ Department of Psychology, Islamic Azad University of Tehran North Branch, Tehran, Iran.

${ }^{2}$ Department of Psychology, Islamic Azad University of Science and Research Branch, Tehran, Iran.

${ }^{3}$ Department of Psychology, Islamic Azad University of Hamedan, Hamedan, Iran.

${ }^{4}$ Department of Psychology, Islamic Azad University of Hamedan, Hamedan, Iran.

*Corresponding Author
} 


\section{Comparison of Catastrophizing and Perceived Stress in Three Groups of Covid-19 Patients Recovered}

with sleep disorders, and 22.9\% with adjustment disorders (Rossi, Socci, Talevi, Mensi, Niolu, Pacitti, Di Marco, Rossi, Siracusano \& Di Lorenzo, 2020). Accordingly, researchers predict that the psychological effects of the pandemic will continue for a long time (Nidhi, 2020). However, the initial concerns of the Corona pandemic were necessarily focused on the ability of primary care services and public hospitals to cope with a potential wave of unpleasant physical illnesses, and its psychological dimension was neglected (Baldwin \& KarlMarlowe, 2021). This is despite the fact that studies on patients and recovered patients show some psychological effects when discharged from the hospital (Niuniu, Luoqun, Hongyun, Xianru, Mingxia, Xinjun \& Suling, 2021) And the other studies on the psychological effects of recovering from Covid-19 disease show that they experience psychological distress (Olasenia, Akinsola, Agberotimi \& Oguntayo, 2020). Other studies on the disease also show social isolation from Covid-19 and a perception of vulnerability (Boyraz, Legros \& Tigershtrom, 2020). However, in general, the experience of illnesses associated with physical pain is also associated with catastrophizing (Sullivan, 2009) and coronavirus disease has symptoms of physical pain. Catastrophizing is a set of cognitive distortions associated with painful events (Sullivan, 2009) and increasing this style of thinking is associated with decreased pain tolerance and an increased tendency to magnify and feel helpless (Schütze, Rees, Preece \& Schütze, 2010). In other words, catastrophizing is a set of cognitions including mental rumination, magnification, and feelings of helplessness (Sullivan, 2009). People with Covid-19, on the other hand, have a perception of stress as a psychological distress (Olasenia et al., 2020). Perceived stress means that people perceive different stresses about the same events because of their different interpretations of events (Houser, Springer \& Pudrovska, 2005). In fact, psychological stress emphasizes the perception of possible harm and is the product of people's interpretation of the relationship with their environment (Lazarus, 1999).

Studies in patients with coronavirus disease are invaluable, yet they were all performed on a group of patients who were experiencing very severe symptoms of the disease. People with milder disease experience are not included. In addition, these studies were performed immediately after recovery, and it is unclear whether these psychological effects will persist for months after recovery. Accordingly, the aim of this study was comparing catastrophized and perceived stress in three groups of Covid-19 patients recovering.

\section{METHODOLOGY}

\section{Sample}

The sample comprised of 97 persons. Volunteers were divided into three groups: patients with respiratory symptoms and hospitalized $(n=22)$, patients with respiratory symptoms and non-hospitalized $(\mathrm{n}=27)$ and patients without respiratory symptoms and non-hospitalized $(n=48)$.

\section{Instruments}

Two measures were used in this study,

- Catastrophizing Questionnaire: The catastrophizing Questionnaire (Sullivan, 2009) is a 13-item tool that assesses three subscales of magnification (3 items), mental rumination ( 4 items), and feelings of helplessness ( 6 items). In this tool, the answers are specified by the Likert method from never to (0) to always (4). The range of scores in this tool for the overall score is between 0 and 52, which higher score means more catastrophizing. For the subscale the magnification is between 0 and 12, the higher score indicates more magnification, for the subscale mental 


\section{Comparison of Catastrophizing and Perceived Stress in Three Groups of Covid-19 Patients \\ Recovered}

rumination is between 0 and 16, the higher score indicates more rumination, and for the subscale the feeling of helplessness is between 0 and 24. A higher score indicates a greater sense of helplessness. This tool has been standardized in Iran by Rahmati et al (2017) and Cronbach's alpha is 0.89 for the whole tool and 0.71 for the rumination subscales, 0.81 for magnification, and 0.81 for helplessness. Cronbach's alpha the data of this tool in the present study were 0.86 for the overall score and $0.73,0.68$, and 0.84 for the subscales, respectively.

- Perceived Stress Questionnaire: The Perceived Stress Questionnaire (Cohen, Kamarck \& Mermelstein, 1983) has 14 items that assess the level of perceived stress. In this tool, the answers are specified by the Likert method from never to (0) to always (4). The range of scores of this tool is between 0 and 56. Higher scores mean more perceived stress and its cut-off point is 21 . The reliability of this tool was obtained by using Cronbach's alpha in the study of Cohen et al (1983) 0.86. This tool was standardized in Iran by Safaei and Shokri (2014) and Cronbach's alpha obtained a total score of perceived stress of 0.76. Cronbach's alpha of this tool in the present study was calculated to be 0.79 .

\section{Procedure}

This was a descriptive study. The statistical population of this study was the visitors of Avaye Dousti Clinic psychometrics system from October to December 2020. Inclusion criteria included the positive result of PCR, and after Two to Four months of recovery from the disease. In order to control these criteria, a demographic questionnaire was used. To comply with the ethical principles of the research, the candidates were asked to study the goals and programs of the research before participating in the research and answered the questionnaires by choosing the option "I agree" the rules of this research. The demographic questionnaire assessed items such as age, gender, recovery time, and positive PCR test result.

\section{RESULTS}

The Table No.1 lists the demographic characteristics of the study.

Table No. 1 Demographic characteristics

\begin{tabular}{lllllll}
\hline \multirow{2}{*}{ Group } & Age & & Sex & & Total & $\begin{array}{l}\text { Average recovery } \\
\text { time (in months) }\end{array}$ \\
\cline { 2 - 5 } & Mean & Std & M & F & & $3 / 1$ \\
\hline $\begin{array}{l}\text { patients with respiratory symptoms } \\
\text { and hospitalized }\end{array}$ & $33 / 33$ & $5 / 08$ & 7 & 15 & 22 & $3 / 6$ \\
\hline $\begin{array}{l}\text { patients with respiratory symptoms } \\
\text { and non-hospitalized }\end{array}$ & $33 / 21$ & $4 / 74$ & 11 & 16 & 27 & $2 / 6$ \\
\hline $\begin{array}{l}\text { patients without respiratory } \\
\text { symptoms and non-hospitalized }\end{array}$ & $26 / 28$ & $6 / 03$ & 17 & 31 & 48 & $2 / 9$ \\
\hline
\end{tabular}

The Table No. 2 describes the research variables.

Table No. 2 Descriptive characteristics of research variables

\begin{tabular}{|c|c|c|c|c|c|c|c|c|c|c|}
\hline \multirow[t]{3}{*}{ Group } & \multicolumn{10}{|c|}{ Variable } \\
\hline & \multicolumn{2}{|c|}{ Catastrophizing } & \multicolumn{2}{|c|}{ Rumination } & \multicolumn{2}{|c|}{ Helplessness } & \multicolumn{2}{|c|}{ Magnification } & \multicolumn{2}{|c|}{$\begin{array}{l}\text { Perceived } \\
\text { Stress }\end{array}$} \\
\hline & Mean & Std & Mean & Std & Mean & Std & Mean & Std & Mean & Std \\
\hline $\begin{array}{l}\text { patients with } \\
\text { respiratory } \\
\text { symptoms and } \\
\text { hospitalized }\end{array}$ & $15 / 11$ & $5 / 17$ & $5 / 66$ & $1 / 66$ & $4 / 97$ & $5 / 43$ & $4 / 48$ & $1 / 08$ & $24 / 45$ & $8 / 66$ \\
\hline patients with & $14 / 08$ & $10 / 07$ & $5 / 77$ & $3 / 34$ & $4 / 29$ & $3 / 77$ & $4 / 02$ & $2 / 39$ & $23 / 44$ & $4 / 23$ \\
\hline
\end{tabular}

(c) The International Journal of Indian Psychology, ISSN 2348-5396 (e)| ISSN: 2349-3429 (p) | 542 


\section{Comparison of Catastrophizing and Perceived Stress in Three Groups of Covid-19 Patients Recovered}

\begin{tabular}{|c|c|c|c|c|c|c|c|c|c|c|}
\hline \multirow{3}{*}{ Group } & \multicolumn{10}{|c|}{ Variable } \\
\hline & \multicolumn{2}{|c|}{ Catastrophizing } & \multicolumn{2}{|c|}{ Rumination } & \multicolumn{2}{|c|}{ Helplessness } & \multicolumn{2}{|c|}{ Magnification } & \multicolumn{2}{|c|}{$\begin{array}{l}\text { Perceived } \\
\text { Stress }\end{array}$} \\
\hline & Mean & Std & Mean & Std & Mean & Std & Mean & Std & Mean & Std \\
\hline \multicolumn{11}{|l|}{$\begin{array}{l}\text { respiratory } \\
\text { symptoms and } \\
\text { non-hospitalized }\end{array}$} \\
\hline $\begin{array}{l}\text { patients without } \\
\text { respiratory } \\
\text { symptoms and } \\
\text { non-hospitalized }\end{array}$ & 9/95 & $4 / 21$ & $4 / 18$ & $1 / 94$ & $2 / 68$ & $2 / 35$ & $3 / 09$ & $1 / 92$ & $21 / 21$ & $9 / 40$ \\
\hline
\end{tabular}

Before performing parametric analysis, the normality of the data was checked using Kolmogorov-Smirnov analysis and the results showed $(\mathrm{P}>0.05)$, so the data are normal. Also, the equality of variances with Leven test was examined and the results showed $(\mathrm{P}>0.05)$, so the variances are equal. Table 3 compares the mean of the research variables in the three groups using analysis of variance.

Table No. 3 Analysis of variance of research variables

\begin{tabular}{|c|c|c|c|c|c|c|}
\hline Variable & & $\begin{array}{l}\text { Sum of } \\
\text { Squares }\end{array}$ & $\overline{\text { Df }}$ & $\begin{array}{l}\text { Mean } \\
\text { Square }\end{array}$ & $\mathbf{F}$ & Sig. \\
\hline \multirow{3}{*}{ Catastrophizing } & Between groups & $362 / 527$ & 2 & $181 / 263$ & $2 / 917$ & $0 / 049$ \\
\hline & Within groups & $5841 / 288$ & 94 & $62 / 141$ & & \\
\hline & Total & $6203 / 814$ & 96 & & & \\
\hline \multirow{3}{*}{ Rumination } & Between groups & $38 / 613$ & 2 & $19 / 307$ & $2 / 646$ & $0 / 050$ \\
\hline & Within groups & $685 / 902$ & 94 & $7 / 297$ & & \\
\hline & Total & $742 / 515$ & 96 & & & \\
\hline \multirow{3}{*}{ Helplessness } & Between groups & $79 / 642$ & 2 & $39 / 825$ & $1 / 998$ & $0 / 048$ \\
\hline & Within groups & $1873 / 382$ & 94 & $19 / 930$ & & \\
\hline & Total & $1953 / 031$ & 96 & & & \\
\hline \multirow{3}{*}{ Magnification } & Between groups & $24 / 091$ & 2 & $12 / 045$ & $3 / 415$ & 0/037 \\
\hline & Within groups & $331 / 538$ & 94 & $3 / 527$ & & \\
\hline & Total & $355 / 629$ & 96 & & & \\
\hline \multirow{3}{*}{ Perceived Stress } & Between groups & $185 / 070$ & 2 & $92 / 535$ & $1 / 402$ & $0 / 251$ \\
\hline & Within groups & $6202 / 600$ & 94 & $65 / 985$ & & \\
\hline & Total & $6387 / 670$ & 96 & & & \\
\hline
\end{tabular}

The findings of Table No. 3 showed that there was a significant difference between the groups in the catastrophizing variable and its subscales, mental rumination, helplessness and magnification $(\mathrm{p}<0.05)$, but there is no significance difference in the perceived stress between the groups $(p>0.05)$. Table No. 4 compares the three groups using the LSD post hoc test.

Table No. 4 LSD post hoc test

\begin{tabular}{lllll}
\hline $\begin{array}{l}\text { Dependent } \\
\text { variable }\end{array}$ & Group one & Group two & $\begin{array}{l}\text { Mean } \\
\text { Differenc }\end{array}$ & Sig. \\
\hline \multirow{4}{*}{ Catastrophizing } & $\begin{array}{l}\text { patients with respiratory } \\
\text { symptoms and non- } \\
\text { hospitalized }\end{array}$ & $\begin{array}{l}\text { patients without respiratory } \\
\text { symptoms and non- } \\
\text { hospitalized }\end{array}$ & $4 / 13$ & $\mathbf{0 / 0 4 5}$ \\
\cline { 2 - 5 } & $\begin{array}{l}\text { patients with respiratory } \\
\text { symptoms and hospitalized }\end{array}$ & $\begin{array}{l}\text { patients without respiratory } \\
\text { symptoms and non- } \\
\text { hospitalized }\end{array}$ & $5 / 16$ & $\mathbf{0 / 0 2 5}$ \\
& patients with respiratory & patients with respiratory & $1 / 03$ & $\mathbf{0 / 5 8 9}$ \\
\hline
\end{tabular}




\section{Comparison of Catastrophizing and Perceived Stress in Three Groups of Covid-19 Patients Recovered}

\begin{tabular}{|c|c|c|c|c|}
\hline $\begin{array}{l}\text { Dependent } \\
\text { variable }\end{array}$ & Group one & Group two & $\begin{array}{l}\text { Mean } \\
\text { Differenc }\end{array}$ & Sig. \\
\hline & symptoms and hospitalized & $\begin{array}{l}\text { symptoms and non- } \\
\text { hospitalized }\end{array}$ & & \\
\hline \multirow{3}{*}{ Rumination } & $\begin{array}{l}\text { patients with respiratory } \\
\text { symptoms and non- } \\
\text { hospitalized }\end{array}$ & $\begin{array}{l}\text { patients without respiratory } \\
\text { symptoms and non- } \\
\text { hospitalized }\end{array}$ & $1 / 59$ & $0 / 047$ \\
\hline & $\begin{array}{l}\text { patients with respiratory } \\
\text { symptoms and hospitalized }\end{array}$ & $\begin{array}{l}\text { patients without respiratory } \\
\text { symptoms and non- } \\
\text { hospitalized }\end{array}$ & $1 / 48$ & $0 / 049$ \\
\hline & $\begin{array}{l}\text { patients with respiratory } \\
\text { symptoms and hospitalized }\end{array}$ & $\begin{array}{l}\text { patients with respiratory } \\
\text { symptoms and non- } \\
\text { hospitalized }\end{array}$ & $-0 / 11$ & $0 / 532$ \\
\hline \multirow{3}{*}{ Helplessness } & $\begin{array}{l}\text { patients with respiratory } \\
\text { symptoms and non- } \\
\text { hospitalized }\end{array}$ & $\begin{array}{l}\text { patients without respiratory } \\
\text { symptoms and non- } \\
\text { hospitalized }\end{array}$ & $1 / 61$ & $0 / 050$ \\
\hline & $\begin{array}{l}\text { patients with respiratory } \\
\text { symptoms and hospitalized }\end{array}$ & $\begin{array}{l}\text { patients without respiratory } \\
\text { symptoms and non- } \\
\text { hospitalized }\end{array}$ & $2 / 29$ & $0 / 049$ \\
\hline & $\begin{array}{l}\text { patients with respiratory } \\
\text { symptoms and hospitalized }\end{array}$ & $\begin{array}{l}\text { patients with respiratory } \\
\text { symptoms and non- } \\
\text { hospitalized }\end{array}$ & $0 / 68$ & $0 / 526$ \\
\hline \multirow{3}{*}{ Magnification } & $\begin{array}{l}\text { patients with respiratory } \\
\text { symptoms and non- } \\
\text { hospitalized }\end{array}$ & $\begin{array}{l}\text { patients without respiratory } \\
\text { symptoms and non- } \\
\text { hospitalized }\end{array}$ & $0 / 93$ & $0 / 050$ \\
\hline & $\begin{array}{l}\text { patients with respiratory } \\
\text { symptoms and hospitalized }\end{array}$ & $\begin{array}{l}\text { patients without respiratory } \\
\text { symptoms and non- } \\
\text { hospitalized }\end{array}$ & $1 / 39$ & $0 / 011$ \\
\hline & $\begin{array}{l}\text { patients with respiratory } \\
\text { symptoms and hospitalized }\end{array}$ & $\begin{array}{l}\text { patients with respiratory } \\
\text { symptoms and non- } \\
\text { hospitalized }\end{array}$ & $0 / 46$ & $0 / 311$ \\
\hline \multirow{3}{*}{$\begin{array}{l}\text { Perceived } \\
\text { Stress }\end{array}$} & $\begin{array}{l}\text { patients with respiratory } \\
\text { symptoms and non- } \\
\text { hospitalized }\end{array}$ & $\begin{array}{l}\text { patients without respiratory } \\
\text { symptoms and non- } \\
\text { hospitalized }\end{array}$ & $2 / 21$ & $0 / 260$ \\
\hline & $\begin{array}{l}\text { patients with respiratory } \\
\text { symptoms and hospitalized }\end{array}$ & $\begin{array}{l}\text { patients without respiratory } \\
\text { symptoms and non- } \\
\text { hospitalized }\end{array}$ & $3 / 24$ & $0 / 126$ \\
\hline & $\begin{array}{l}\text { patients with respiratory } \\
\text { symptoms and hospitalized }\end{array}$ & $\begin{array}{l}\text { patients with respiratory } \\
\text { symptoms and non- } \\
\text { hospitalized }\end{array}$ & $1 / 01$ & $0 / 66$ \\
\hline
\end{tabular}

The findings of Table No. 4 showed that catastrophizing and its subscales, mental rumination, feeling of helplessness and magnification, in the group with respiratory and hospitalized symptoms and the group with respiratory and non-hospitalized symptoms There is no significant difference $(\mathrm{p}>0.05)$ but the same variables are significantly different compared to the group without respiratory symptoms and non-hospitalization $(\mathrm{p}<0.05)$. Also, the perceived stress between the three groups was not significantly different $(p>0.05)$ and in all three groups it was higher than the cut-off point of the general population.

\section{DISCUSSION}

The findings of this study showed that catastrophizing in patients with Covid-19 disease is seen in patients with more severe symptoms for at least a few months after recovery and high perceived stress was observed in all patients without significant differences (Tables No.3 and No.4). 


\section{Comparison of Catastrophizing and Perceived Stress in Three Groups of Covid-19 Patients Recovered}

Although researcher's study shows that so far no research has been done exactly similar to the present study to compare the findings of this study, but the findings of this study in terms of the existence of different psychological effects of coronavirus disease with the findings of Niuniu et al (2021), Olasenia et al (2020) and Boyraz et al (2020) are consistent.

In explaining these findings, we can say: Researchers in the early days of the pandemic predicted that the psychological effects would continue for a long time. In this study, it was found that the mean scores of catastrophizing and its subscales, ie mental rumination, feeling of helplessness and magnification, were higher in groups with very severe and severe symptoms than in the group with mild symptoms. On the other hand, the association of catastrophizing with the experience of diseases associated with physical pain, which coronavirus disease is also associated with physical pain, justifies the high scores of catastrophe in groups with very severe symptoms and severe symptoms. They may also feel helpless about possible future physical complications and the ambiguity of the residual physical effects of the disease. Also, in explaining these findings, in the sense that the perceived stress was not significantly different between the three groups, it can be said: All three groups in this study were somehow faced with symptoms that the disease was unpredictable and ambiguous, so they experienced a relatively equal level of stress. The results also showed that the perceived stress levels of the three groups were not significantly different. The cut-off point for the general population indicates that individuals in all three groups perceived more stress than the general population.

This research, like other studies, has limitations. Among these limitations, it can be said that the subjects were not available before the onset of the disease, and it cannot be said with certainty that the perceived catastrophizing and Perceived Stress were due to the experience of Covid-19 disease. Therefore, researchers are suggested to conduct similar longitudinal studies on the psychological effects left on the recovered so that during these longitudinal studies, the psychological dimensions of Covid-19 disease can be identified with more confidence. Also, according to the findings of this study, it is suggested that psychological counseling be provided by psychologists, counselors and social workers in health centers, clinics \& ... for patients. Also, it is suggested that psychological training programs through the media collectively and socially be on the agenda of governments.

\section{REFERENCES}

Baldwin, D; KarlMarlowe, R. (2021). The roles of a psychiatrist in the COVID-19 pandemic. Clinics in Integrated Care, 4: 100036.

Boyraz, G; Legros, D \& Tigershtrom, A. (2020). COVID-19 and traumatic stress: The role of perceived vulnerability, COVID-19-related worries, and social isolation, Journal of Anxiety Disorders, 76: 102307.

Cohen, S; Kamarck T \& Mermelstein, R. (1983). A global measure of perceived stress. Journal of Health and Social Behavior, 24(4): 385-396.

Dousti, P; Hosseininia, N; Ghodrati, G \& Ebrahimi M. E. (2020). Comparison of rumination, Sense of helplessness, and magnification at different ages and their relation to stress coping styles in visitors of a mental health monitoring website during the first week of coronavirus outbreaks. Knowledge \& Research in Applied Psychology, 21(2): 105-114.

Houser, R; M; springer, K. W \& Pudrovska, T. (2005). "Temporal structures of psychology well-being: Continuity or Change". Presented at the 2005 Meetings of the 


\section{Comparison of Catastrophizing and Perceived Stress in Three Groups of Covid-19 Patients Recovered}

Gerontogical society of America, orlando, Florida. University of Wisconsin-Madison Department of Sociology Center for Demography of Health and Aging.

Lazarus, RS. (1999). Stress and emotion: A new synthesis. London, UK: Free associaton books.

Nidhi, S. (2020). Traumatic Skepticism of COVID-19. International Journal of Multidisciplinary Perspectives in Higher Education, 5(1): 84-88.

Niuniu, S; Luoqun, W; Hongyun, W; Xianru, W; Mingxia, G; Xinjun, H \& Suling, S. (2021). Qualitative study of the psychological experience of COVID-19 patients during hospitalization, Journal of Affective Disorders. 278: 15-22.

Olasenia, A; Akinsola, O; Agberotimi, S \& Oguntayo, R. (2020). Psychological distress experiences of Nigerians during Covid-19 pandemic; the gender difference, Social Sciences \& Humanities Open. 2(1): 100052.

Rahmati, N; Asghari Moghadam, M. A; SHAIRI, M; Paknejad, Rahmati, Z; Ghassami, M et al . (2017). A Study of the Psychometric Properties of the Pain Catastrophizing Scale Amongst Iranian Patients with Chronic Persistent Pain, Journal of Ilam University of Medical Sciences. 25(1): 63-79.

Rossi, R; Socci, V; Talevi, D; Mensi, S; Niolu, C; Pacitti, F; Di Marco, A; Rossi, A; Siracusano, A \& Di-Lorenzo, G. (2020). COVID-19 Pandemic and Lockdown Measures Impact on Mental Health Among the General Population in Italy, Frontiers in Psychiatry. 11: 790.

Safaei, M \& Shokri, O. (2014). Assessing Stress in Cancer Patients: Factorial Validity of the Perceived Stress Scale in Iran, Iranian Journal of Psychiatric Nursing. 2(1): 13-22.

Schütze, R; Rees, C; Preece, M \& Schütze, M. (2010). Low Mindfulness Predicts Pain Catastrophizing in a FearAvoidance, Model of Chronic Pain, Pain. 148: 120-27.

Sullivan, M. J. (2009). Catastrophizing Scale. Departments of Psychology, Medicine, and Neurology School of Physical and Occupational Therapy McGill University Montreal, Quebec.

\section{Acknowledgement}

The author(s) appreciates all those who participated in the study and helped to facilitate the research process.

\section{Conflict of Interest}

The author(s) declared no conflict of interest.

How to cite this article: Dousti P., Hosseininia N., Dousti P. \& Dousti S. (2021). Comparison of Catastrophizing and Perceived Stress in Three Groups of COVID-19 Patients Recovered. International Journal of Indian Psychology, 9(2), 540-546. DIP:18.01.056.20210902, DOI:10.25215.0902.056 